\title{
Satisfaction with Inclusive Education Services and its Relationship with Father and Mother Involvement
}

\author{
Annas Dwi Setyarini ${ }^{1}$, Yunita Hardian Putri ${ }^{2}$, Fatma Putri Sekaring Tyas ${ }^{3}$, Alfiasari ${ }^{\left.4^{*}\right)}$ \\ ${ }^{1} \mathrm{SD}$ Al Fityan School Tangerang, Indonesia \\ ${ }^{2}$ SD Karakter, Indonesia Heritage Foundation, Cimanggis, Depok, Indonesia \\ ${ }^{3,4}$ Department of Family and Consumer Sciences, Faculty of Human Ecology, IPB University, \\ 16680 Bogor, Indonesia
}

*) Corresponding author: alfiasari@ apps.ipb.ac.id

\begin{abstract}
Parental involvement in education is essential, especially for children with special needs and the existence of inclusive schools supports children's education fairly so that inclusive education services need to prioritize services to achieve parental satisfaction. The purpose of this study was to analyze parental satisfaction with inclusive education services and their relationship to parental involvement. This research was conducted in one of the inclusive schools in East Jakarta. Samples in this study are mothers and fathers from intact families with children with special needs who attend inclusive schools with purposive sampling technique with as many as 30 married couples. The results show a significant positive relationship between the variables of mother's satisfaction with father's satisfaction and father's engagement with father's satisfaction. Moreover, mother's engagement was significantly related to mother's education, while mother's satisfaction positively correlated with mother's age. A significant negative relationship was found between mother's satisfaction and father's education; father's engagement with child's age and length of getting inclusive services. The effect test found that the father's satisfaction was significantly affected by father's involvement and mother's satisfaction, while mother's satisfaction was significantly affected by mother's age and father's satisfaction. Inclusive schools need to provide optimal services and involve parents in schools to feel satisfied.
\end{abstract}

Keywords: educational services, inclusive schools, parental involvement, parental satisfaction, special needs children

\begin{abstract}
Abstrak
Keterlibatan orang tua dalam bidang pendidikan sangat penting, terutama pada anak berkebutuhan khusus dan keberadaan sekolah inklusif mendukung pendidikan anak secara adil sehingga layanan pendidikan inklusif perlu mengutamakan pelayanan untuk mencapai kepuasan orang tua. Tujuan penelitian ini adalah untuk menganalisis kepuasan orang tua pada layanan pendidikan inklusif dan keterkaitannya dengan keterlibatan orang tua. Penelitian ini dilakukan di salah satu sekolah inklusif di wilayah Jakarta Timur. Contoh dalam penelitian ini adalah ibu dan ayah dari keluarga utuh dengan anak berkebutuhan khusus yang bersekolah di sekolah inklusif dengan teknik pengambilan contoh purposive sampling dengan responden sebanyak 30 pasangan suami istri. Hasil penelitian menunjukkan adanya hubungan positif signifikan pada variabel kepuasan ibu dengan kepuasan ayah serta keterlibatan ayah dengan kepuasan ayah. Hasil uji hubungan lainnya menemukan keterlibatan ibu berhubungan positif signifikan dengan pendidikan ibu; sedangkan kepuasan ibu berhubungan positif signifikan dengan usia ibu. Hubungan negatif signifikan ditemukan antara kepuasan ibu dengan pendidikan ayah serta keterlibatan ayah dengan usia anak dan lama mendapatkan layanan inklusif. Uji pengaruh menemukan kepuasan ayah dipengaruhi positif signifikan oleh keterlibatan ayah dan kepuasan ibu, sementara kepuasan ibu dipengaruhi positif signifikan oleh usia ibu dan kepuasan ayah.
\end{abstract}


Penting bagi sekolah inklusif memberikan pelayanan yang optimal serta melibatkan orang tua di sekolah sehingga orang tua merasa puas.

Kata kunci: anak berkebutuhan khusus, kepuasan orangtua, keterlibatan orangtua, layanan pendidikan, sekolah inklusif

\section{Introduction}

Education is an important process to optimize the development of children, including children with special needs. Children with Special Needs (CSN) also have the right to get an education to optimize their growth, development, and potential, regardless of their special circumstances. The Government of the Republic of Indonesia, through Government Regulation Number 17 of 2010 concerning the Management of Education Implementation Article 133 has regulated the implementation of special schools at the basic and secondary education levels. The regulation explains that CSN has the same opportunities and school services as regular students. In addition, CSN can also take education in integrated schools. Integrated schools are regular schools that accept children with special needs, with the same curriculum and infrastructure for all students. Integrated schools are better known as inclusive schools (Kemendikbud, 2016).

Meanwhile, Permendiknas Number 70 of 2009 concerning Inclusive Education for Students with Disabilities and Potential Intelligence and/or Special Talents, in article 1 states that inclusive education is an education system that provides opportunities for all students who have disabilities and have disabilities. The potential for intelligence and/or special talent to participate in education or learning in an educational environment together with students in general. In the regulation, it is stated that the purpose of inclusive education is 1) to provide the widest possible opportunity for all students who have physical, emotional, mental, and social disabilities or have the potential for intelligence and/or special talents to obtain quality education in accordance with their needs and abilities; and 2) realizing the implementation of education that respects diversity, and is not discriminatory for all students. While the students referred to in the regulation are visually impaired, deaf, speech impaired, mentally retarded, physically disabled, mentally retarded, learning difficulties, slow learners, autistic, have motor disorders, become victims of drug abuse, illegal drugs and other addictive substances, have other disorders, and double disability.

Inclusive education involves a systemic reform process that brings about changes and modifications in content, teaching methods, approaches, structures and strategies in education to overcome barriers with a vision of serving to provide all students of the relevant age range with a fair and participatory learning experience and an environment that is most according to their needs and preferences (Hehir et al., 2016). Data from the Ministry of Education and Culture (2016), the total number of children with special needs in Indonesia in November 2015 reached 1.6 million children, and there are still few who want to go to school because children do not want to go to school, parents are less supportive, and access to schools is far so difficult to reach. The condition of CSN sometimes makes parents feel pressured and embarrassed when sending their children to special places such as Special Schools (SLB) so that the choice of inclusive schools is considered more appropriate. However, not all regular schools provide adequate facilities for CSN. 
The results of Tarnoto's research (2016) showed that the various problems faced by schools when implementing inclusive education at the elementary level are that there are various problems encountered by teachers related to the readiness of the school itself, such as the lack of teacher competence in dealing with CSN students and also problems related to the lack of parental concern for CSN. In addition, the large number of CSN students in one class and the lack of cooperation from various parties such as the community, professional experts and the government are still challenges. Based on the description of the study from the Ministry of Education and Culture (2016), it can also be seen that all junior high schools providing inclusive education in Indonesia have not been able to adequately meet the needs of Special Assistant Teachers (SAT) according to the specific type of student. Every education unit that provides inclusive education is required to provide at least 1 (one) SAT, not all of which are fulfilled. In addition, the placement of SAT is also not evenly distributed between public and private schools, between regions and based on specificity. The lack of training for teachers in the field of skills in dealing with students with special needs is also a challenge to fulfil in inclusive schools. Pratiwi (2015) stated that one factor that hinders the implementation of inclusive education is teachers who have not been able to handle children with special needs in regular classes. This is also in line with Subbey's research (2017) which found that teachers do not have the necessary skills and facilities to teach in an inclusive classroom environment. This, of course, affects the fulfilment of the needs of CSN in obtaining their education rights, as expressed by Evans and Lunt (2002), which stated that the obstacles to implementing inclusive education are related to the ability to meet the of children with special needs.

The hope is that inclusive schools have at least one accompanying teacher. It is necessary to map and place assistant teachers according to CSN needs and organize training for CSN teachers (Kemendikbud, 2016). Various challenges and problems in the implementation of inclusive education should not leave an important actor, namely parents of children with special needs. Parents are also one of the parties who determine success in inclusive education for children with special needs. Brydges and Mkandawire (2018) illustrate that parents have different views about inclusive education. Some parents consider that inclusive education can be more beneficial for their children and is the best choice. However, outside of school, parents, especially mothers, tend to feel that they experience negative attitudes and stigma, which hinders CSN's access to education and experiences social pressure. The negative stigma received by the mother because she was blamed for giving birth to CSN has an impact on the family and parents' work.

Several previous research results have found a link between parental satisfaction and educational services, including a significant relationship between educational services and parental satisfaction (Alotaibi, 2017; Ningsih, Imron, \& Triwiyanto, 2018; Sari \& Prasetya, 2020). Indrawati (2011) stated that there are five qualities of educational services (reliability, direct evidence, capture power, assurance, empathy) that have a significant positive effect on customer satisfaction (parents). In addition, other studies have also found that satisfaction levels vary significantly according to the mother's education and family income level (Hidalgo, McIntyre, McWhirter \& Ellen, 2015). Abdullah's research (2020) shows a positive and significant influence between the education management information system and the social competence of teachers together on parental satisfaction. Utami and Putra (2020) also found that the availability of special services such as special rooms for CSN, including study rooms, meditation 
rooms, and parent consultation rooms, are closely related to parental satisfaction with inclusive education services. The results of these studies indicate that it is important for educational institutions to develop services that are oriented towards the satisfaction of parents as parties who are also interested in providing the best education rights for their children; especially for CSN by providing additional accompanying teachers who have skills in accordance with CSN.

In addition to providing services directly from inclusive schools that can increase satisfaction with inclusive education services, involved parents are also a key factor. According to Afolabi (2014), parental involvement is important in supporting children's achievement and inclusive education. The results of Griffith's research (1996) also showed that parental satisfaction is moderated by several factors, including the way to treat parents, inform and empower parents, and the process of involving parents properly will shape their perception of a positive school climate. In addition, other results of Griffith (1996) and Heiserman (1994) showed that there is a relationship between parental satisfaction and parental involvement in the field of children's education in schools. However, research on parental satisfaction with educational services and its relationship to parental involvement, especially on inclusive education services in Indonesia, is still limited. Therefore, it is important to conduct this research because it is a part of developing the education of children with special needs without discriminating in providing services and educational rights. This study analyses parental satisfaction with inclusive education services and their relationship to parental involvement. Through this research, it is expected to contribute ideas for improving inclusive education services so that the right to obtain the best education and according to the needs of children with special needs can be maximally fulfilled.

\section{Methods}

\section{Participants}

This study uses a quantitative approach with an explanatory design to answer the research hypothesis that parental involvement in children's inclusive education affects parents' satisfaction with children's inclusive education. The research location is a State Elementary School (SDN) located in East Jakarta City, DKI Jakarta Province, which was selected purposively. The research was carried out from January to August 2017, including the preparation of research proposals, data collection, data processing, data analysis, and writing research reports. In the data collection process, initially, the researcher visited the selected inclusive school and obtained data on 94 children with special needs. From the data selected according to the sample criteria, namely having a father and mother who are still complete so that 46 sample frames of CSN are obtained from which the data of the father and mother will be taken. Furthermore, the researchers distributed questionnaires to 46 fathers and mothers and were given the opportunity to fill out the questionnaires for two days. From this process, only 30 couples (mother and father) returned a complete questionnaire, which became the data processed in this study.

\section{Measurement}

The primary data collected in this study included the characteristics of children (age, gender, type of special needs, and duration of receiving inclusive services), family 
characteristics (age of father and mother, last education of father and mother, occupation of father and mother, family income, and family size), parental satisfaction, and parental involvement. Parental satisfaction is a feeling that arises as a form of performance assessment of inclusive education services covering all services received by parents with children with special needs. Parental satisfaction was measured using the Special Education Service Client Satisfaction Survey 2015 instrument made by Evidence, Data \& Knowledge Group Ministry of Education (2016). Parental satisfaction was measured using 13 statements, but in this study, the questions were modified and deleted because they were not in accordance with the culture and characteristics of the sample so that they used 12 questions. The removed statement was, "I feel culture affects the service I get". The statement was deleted because the culture and characteristics of the respondents at the place of data collection were different. The modified statement is in number 13, which is "I am satisfied with my child's inclusive service because it is in accordance with the costs I incur". In addition, this instrument was also modified on the answer scale to a five-point Likert scale consisting of $1=$ strongly disagree, $2=$ disagree, $3=$ neutral given, $4=$ agree, and $5=$ strongly agree. As a result, the value of Cronbach's alpha of the father's satisfaction instrument is 0.846 , while the mother's satisfaction is 0.789 .

Parental involvement is the contribution of parents in supporting children's education with special needs. Parental involvement was measured using the Family Involvement Question (FIQ) instrument developed by Fantuzzo, Tighe, and Childs (2000). The measurement of parental involvement in the FIQ is divided into three dimensions, namely parental involvement in school, parental involvement at home, and parental relationship with the school. Parental involvement was measured using 34 statements. Each dimension consisted of 10 questions for parental involvement in school, 13 statements for parental involvement at home, and 11 statements for the relationship between parents and school. This study made modifications to the questions in statement number 10 section on relations with schools, namely "I talk to teachers by telephone" to "I talk to teachers through various communication media". This instrument uses a four-point Likert scale consisting of $1=$ never, $2=$ rarely, $3=$ often, and $4=$ always with the Cronbach's alpha value of the father's involvement instrument of 0.931 , while the mother's involvement is 0.733 .

\section{Analysis}

The data that has been collected is then processed through the process of editing, coding, scoring, entering, cleaning, and data analysis. The scores of parental satisfaction and parental involvement were then transformed into an index of 0-100. Data processing and analysis were carried out using the Statistical Package for Social Science (SPSS) program. SPSS was used to examine the relationship between variables and the effect between research variables. Analysis of the relationship uses the spearman correlation test because several data are categorized, while the effect analysis uses a linear regression test. 


\section{Findings}

\section{Child Characteristics}

Children with special needs are 8-13 years, with an average of 10.23 years. Age selection is by the availability of children in selected inclusive primary schools. As many as 60 per cent are male, and 40 per cent are female. In this study, all children had intellectual disabilities, which were categorized into three types of special needs, namely mental retardation (IQ <70), borderline (IQ 70-79), and slow learners (IQ 8090). The proportions are not much different between the three types of crew members based on the research data. For children with Special Needs in this study, the largest proportion is the borderline type of special needs (37.0\%); followed by the type of special needs mentally retarded $(33.0 \%)$ and slow learners $(30.0 \%)$. Meanwhile, based on the length of time children receive inclusive services in this study, it ranges from 1-6 years. The results showed that not all children received inclusive services since grade 1 level, but some children were newly detected as having learning disorders/delays after the school held an IQ test.

\section{Family Characteristics}

The results describe the mean age of the father as 43.57 years, and the average age of the mother is 39.6 years. Parents' education is categorized into two: not graduating from elementary school - completing junior high school and graduating from high school - bachelor's degree. This category shows that more than half of fathers $(63.3 \%)$ graduated from high school, and the remaining 36.7 per cent did not finish elementary school-junior high school. Meanwhile, almost three-quarters of mothers $(73.3 \%)$ graduated from high school-bachelor, and the remaining 26.7 per cent did not finish elementary school finished high school. The average per capita income of a family with a child with special needs is IDR 520,259.25.

\section{Relationship between Father and Mother's Involvement and Satisfaction with Inclusive Services}

The results of the correlation test conducted in this study showed a significant positive relationship between the variables of mother's satisfaction and father's satisfaction $(r=0.370 ; p=>0.05)$. These results indicate that the more satisfied mothers with inclusive education services, the fathers will feel better satisfaction. In addition, the father's involvement variable was also significantly positively related to father's satisfaction $(\mathrm{r}=0.634 ; \mathrm{p}=>0.01)$. This means that fathers who are satisfied with their children's inclusive services are highly involved in their children's education at school and at home and have good relationships with schools.

The mother involvement variable was significantly positively related ( $\mathrm{r}=0.383$; $\mathrm{p}=>0.05$ ) with the mother's education. This means that if the mother has a fairly high education and has a stock of knowledge about the needs of children with special needs, they are more often involved in the process of childcare and education. Mother's age was positive correlate to mother's satisfaction significantly $(r=0.454 ; p=>0.05)$. These results can be stated that the more mature the mother's age, the mother has various points of view on the inclusive services received for the child so that the mother can feel more satisfied. Meanwhile, other results showed a significant negative relationship between mothers' satisfaction with their father's education $(r=-0.393 ; p=>0.05)$. This means that the mother will be dissatisfied with the inclusive services if the father has a 
high education. This can be caused because when the father's education is higher, the father has more expectations and demands for school, which can make the mother feel dissatisfied.

Father involvement was significantly negatively related to the child's age ( $\mathrm{r}=-$ $0.389 ; \mathrm{p}=>0.05)$ and length of receiving inclusive services $(\mathrm{r}=-0.437 ; \mathrm{p}=>0.05)$. This means that the father's involvement will decrease when the child is older, this condition can occur because the father is increasingly busy at work and feels that the child is much more independent compared to young age. Meanwhile, fathers' involvement also decreases when they receive long-standing inclusive services. This may be due to the fact that the services provided by the school are almost the same every year, which makes fathers less involved in their children's education and can also be caused by the age of the children who are getting older so that fathers reduce their involvement in school.

Table 1. Coefficient of correlation test between father and mother's involvement and satisfaction with inclusive services

\begin{tabular}{|c|c|c|c|c|}
\hline Variable & $\begin{array}{r}\text { Mother's } \\
\text { involvement }\end{array}$ & $\begin{array}{r}\text { Mother's } \\
\text { Satisfaction }\end{array}$ & $\begin{array}{r}\text { Father's } \\
\text { involvement }\end{array}$ & $\begin{array}{r}\text { Father's } \\
\text { Satisfaction }\end{array}$ \\
\hline Father's age & 0.257 & 0.266 & -0.245 & 0.203 \\
\hline Father's education ${ }^{1)}$ & 0.076 & $-0.393^{*}$ & 0.120 & 0.101 \\
\hline Mother's age & -0.081 & $0.454^{*}$ & -0.324 & 0.001 \\
\hline Mother's education 2) & $0.383^{*}$ & -0.188 & 0.004 & -0.127 \\
\hline Income per capita & 0.149 & -0.286 & -0.096 & 0.074 \\
\hline Child gender & 0.004 & 0.273 & 0.268 & 0.234 \\
\hline Child's age & -0.275 & 0.271 & $-0.389^{*}$ & -0.239 \\
\hline Inclusive service duration & -0.045 & -0.074 & $-0.437^{*}$ & -0.097 \\
\hline Mother's involvement & 1 & 0.106 & 0.210 & 0.306 \\
\hline Mother's Satisfaction & & 1 & 0.051 & $0.370^{*}$ \\
\hline Father's involvement & & & 1 & $0.634^{* *}$ \\
\hline Father's Satisfaction & & & & 1 \\
\hline
\end{tabular}

*Note: 1) 2$)=(0=$ did not finish elementary school-graduated junior high; $1=$ graduated from high schoolundergraduate); ${ }^{*}: \mathrm{p}>0.05 ; * *: \mathrm{p}>0.01$

\section{The Effect of Characteristics, Involvement and Satisfaction of Fathers and Mothers on Inclusive Services}

Overall, the regression model in Table 2 explains that 34.2 per cent of the variables in the regression model affect fathers' satisfaction with inclusive services, while other variables outside of this study influence the remaining 65.8 per cent. The results of linear regression analysis showed that father's involvement $(B=0.362 ; p<0.01)$ had a significant positive effect on father's satisfaction with inclusive services. This means that every one-unit increase in father's involvement will also increase father's satisfaction with inclusive services by 0.362 points. Other results mother's satisfaction $(B=0.490 ; p<0.01)$ had a significant positive effect on father's satisfaction with inclusive services. This means that each increase of one unit of mother's satisfaction will optimize father's satisfaction with inclusive services by 0.490 points.

Meanwhile, the regression results that affect mother's satisfaction are 31.3 per cent and other variables outside this study influence the remaining 69.7 per cent. The results of Table 2 show that mother's age $(B=0.654 ; \mathrm{p}<0.05)$ positively affects mother's satisfaction with inclusive services. This means that every one-unit increase in mother's age will optimize mother's satisfaction with inclusive services by 0.654 points. In 
addition to other results, father satisfaction $(B=0.350 ; \mathrm{p}<0.01)$ had a significant positive effect on mother's satisfaction with inclusive services. This means that every one unit increase in the father's satisfaction will optimize the mother's satisfaction with inclusive services by 0.350 points.

Table 2. The results of the linear regression test of independent variables on the satisfaction of fathers and mothers with inclusive education services

\begin{tabular}{|c|c|c|c|c|c|c|c|}
\hline \multirow{2}{*}{ Variable } & \multicolumn{3}{|c|}{ Father's Satisfaction } & \multirow{2}{*}{ Variable } & \multicolumn{3}{|c|}{ Mother's Satisfaction } \\
\hline & $\mathrm{B}$ & $\mathrm{B}$ & Sig. & & $\mathrm{B}$ & $\mathrm{B}$ & Sig. \\
\hline Constant & 15.264 & & 0.489 & Constant & 8.481 & & 0.671 \\
\hline $\begin{array}{l}\text { Father's age } \\
\text { (year) }\end{array}$ & 0.201 & 0.141 & 0.437 & $\begin{array}{l}\text { Mother's age } \\
\text { (year) }\end{array}$ & 0.654 & 0.381 & $0.058^{*}$ \\
\hline $\begin{array}{l}\text { Father's } \\
\text { education }{ }^{1)}\end{array}$ & 5.130 & 0.240 & 0.231 & $\begin{array}{l}\text { Mother's } \\
\text { education }\end{array}$ & -5.661 & -0.258 & 0.252 \\
\hline $\begin{array}{l}\text { Income per } \\
\text { capita }\end{array}$ & $-1.078 \mathrm{E}-7$ & 0.027 & 0.871 & $\begin{array}{l}\text { Income per } \\
\text { capita }\end{array}$ & $-6.503 E-7$ & -0.175 & 0.295 \\
\hline $\begin{array}{l}\text { Gender of } \\
\text { dummy } \\
(0=\text { male, } \\
1=\text { female })\end{array}$ & 0.466 & 0.022 & 0.901 & $\begin{array}{l}\text { Gender of } \\
\text { dummy } \\
(0=\text { male, } \\
1=\text { female })\end{array}$ & 1.212 & 0.060 & 0.751 \\
\hline $\begin{array}{l}\text { Child's age } \\
\text { (year) }\end{array}$ & -0.151 & -0.025 & 0.903 & $\begin{array}{l}\text { Child's age } \\
\text { (year) }\end{array}$ & 1.407 & 0.250 & 0.206 \\
\hline $\begin{array}{l}\text { Inclusive } \\
\text { service } \\
\text { duration } \\
\text { (year) }\end{array}$ & 1.177 & 0.130 & 0.471 & $\begin{array}{l}\text { Inclusive } \\
\text { service duration } \\
\text { (year) }\end{array}$ & -2.062 & -0.241 & 0.226 \\
\hline $\begin{array}{l}\text { Father's } \\
\text { involvement }\end{array}$ & 0.362 & 0.537 & $0.019^{* *}$ & $\begin{array}{l}\text { Mother's } \\
\text { involvement }\end{array}$ & 0.185 & 0.234 & 0.228 \\
\hline $\begin{array}{l}\text { Mother's } \\
\text { involvement }\end{array}$ & 0.012 & 0.015 & 0.936 & $\begin{array}{l}\text { Father's } \\
\text { involvement }\end{array}$ & -0.033 & -0.052 & 0.827 \\
\hline $\begin{array}{l}\text { Mother's } \\
\text { Satisfaction }\end{array}$ & 0.490 & 0.461 & $0.024^{* *}$ & $\begin{array}{l}\text { Father's } \\
\text { Satisfaction }\end{array}$ & 0.350 & 0.372 & $0.079^{*}$ \\
\hline Adjusted $\mathrm{R}^{2}$ & & 0.342 & & Adjusted $\mathrm{R}^{2}$ & & 0.313 & \\
\hline R-Square & & 0.547 & & R-Square & & 0.526 & \\
\hline $\mathrm{F}$ & & 2.678 & & $\mathrm{~F}$ & & 2.470 & \\
\hline Sig & & $0.032^{* *}$ & & Sig & & $0.044^{* *}$ & \\
\hline
\end{tabular}

\section{Discussion}

This research was conducted on parents of children with special needs with limited IQ or, commonly referred to as intellectual disability. In addition, some call the term mental retardation. Mental retardation is a comprehensive decline in intellectual function that significantly and directly causes impaired social adaptation, and manifests during the developmental period and is classified into mental retardation, namely: mild retardation, moderate retardation, severe retardation and profound retardation (Sularyo \& Kadim, 2000). The study of Sularyo and Kadim (2000) also explained that mild mental retardation is categorized as educable mental retardation, which means that children have language disorders but can still master it for daily speaking purposes and for clinical interviews. Moderate mental retardation is categorized as trainable mental retardation. In this group, children experience delays in developing understanding and use of language, and their ultimate achievement is limited. This group of severe mental retardation is almost the same as moderate mental retardation in terms of clinical features, organic causes, and associated conditions. Very severe mental retardation means that practically the child is very limited in his ability to understand 
and obey requests or instructions. In the study, it was also concluded that the factors that cause mental retardation could not be separated from the growth and development factors of children, while the biggest factor is genetics that is passed down from parents to children, namely chromosomal abnormalities that children inherit. In addition, the environment is also a factor in children experiencing mental barriers, judging by how the child's situation and environment are growing and developing, a good environment will help children in their social context to be able to interact.

According to Setiawati (2019), intellectual disabilities are known if they have an IQ below 70 along with limited adaptive functions. The limitations of adaptive function can be assessed from three areas of ability, namely conceptual, social, and practical that a person needs in daily life. Conceptual areas include language, reading, writing, mathematics, reasoning, knowledge, and memory. The social area includes empathy, social judgment, and interpersonal communication skills, while the practical area includes self-care skills. In addition, to assess the presence or absence of adaptive function limitations, there must be a significant deficit in at least one of the three areas.

This study focuses on fathers and mothers who have children with intellectual disabilities who are categorized into three types of special needs, namely mental retardation (IQ <70), borderline (IQ 70-79), and slow learners (IQ 80-90). This limitation is not immediately known by parents when their children enter school. Parents only find out if their child has intellectual limitations after taking an IQ test and getting some learning reports from school. The condition of such children also makes parents worried, stressed, and embarrassed. Parents will also experience increased stress when the age of children with special needs has reached school age, so parents must choose the right educational services to meet the needs of their children (Wehrmann, 2015). Along with the development of the world of education that provides inclusive schools, this school is considered an option and helps parents keep their children in school.

Inclusive schools are a new development of integrated education and are adapted to their particular needs, all of which are sought to be served optimally by making various modifications and or adjustments, starting from the curriculum, facilities and infrastructure, teaching and educational staff, the learning system to the assessment system. All students in the inclusive education program will get the same treatment at school; the difference is that students with special needs will receive assistance from special assistant teachers (SAT) (Kemendikbud, 2016). According to the Ministry of Education and Culture (2011), the principle of inclusive education is the principle of equity and quality improvement, the principle of diversity, the principle of meaningfulness, the principle of sustainability, and the principle of involvement. Meanwhile, according to the Ministry of Education and Culture (2016), the components in inclusive education are student management, curriculum management, teaching staff management, facilities and infrastructure management, financial/funding management, environmental management (school and community relations), and special service management. Management of special services in question is a process of activities that provide services to the needs of students to support learning activities so that educational goals can be achieved effectively and efficiently. Schools' special management services include guidance and counselling, libraries, school health services, extracurriculars, cooperatives, canteens, and inclusive classes. According to Boscardin and Jacobson (1997), the inclusive school approach provides the best service to their students by fostering a sense of community and promoting ways to promote solidarity and diversity simultaneously. His research also states that creating inclusive schools focusing on diversity can affect students' self-concept, self-esteem, and achievement.

However, in some cases the implementation of inclusive schools in Indonesia has encountered several obstacles such as the lack of education funding, inadequate supporting facilities and infrastructure, and the lack of accompanying teachers for special participants for children with special needs (Agustin, 2016); students and learning are obstacles in implementing inclusive education, meanwhile management, students, and learning are the most 
important factors that must be considered in the implementation of the inclusive education model so that an inclusive education model is developed which consists of three stages, namely input (management of the physiological environment, physical environment, and psychotic environment), process (Instructional Management is a dynamic process to produce a dynamic system, an ecosystem in which there is a balance between various environmental elements), and output (Development of the quality of intelligent students, meaning that with careful planning in the delivery of inclusive education, its function is to produce intelligent students) (Robiyansah, 2020).

Sujarwanto, Riyanto, and Ashar (2018) describe that implementing student management in inclusive schools is quite good, including planning, organizing, implementing, supervising, and evaluating. The planning aspect still requires improvements to the new student registration team. The supporting factors in the implementation of student management are optimal support from various parties and an inclusive culture that has developed well, while the inhibiting factors in student management are direct support from parents and the lack of knowledge and experience of teachers. Based on the results of the literature review research from Musyafira and Hendriani (2021) by means of a literature study, it is stated that one of the successes of inclusive education is if the teacher has a positive attitude which can be seen from the teacher's readiness to accept children with special needs in the classroom, meanwhile experience, length of teaching and training can influence differences in teacher attitudes towards inclusive education. Teachers with more and longer experience are considered to have more positive attitudes towards inclusive education. Especially teachers who have experience with students with special needs show a more positive attitude towards inclusive education. Research conducted by Sutisna et al. (2020) at an elementary school in Lombok illustrates that the implementation of inclusive schools is quite good, this can be seen from the integrated teaching and learning process between students with special needs and regular students forcing schools to adjust the curriculum to facilitate students with special needs without overriding regular students so that some changes on the syllabus and lesson plans, especially on indicators of competency achievement, learning objectives, learning materials and learning evaluation. For educators, schools are facilitated by the Ministry of Education and Culture, which was formed in collaboration with the Australian government with the INOVASI program so that teachers and schools receive guidance, direction and training to handle students with special needs integrated in regular classes. For inclusive education facilities and infrastructure are still lacking, so they still need to be developed and organized to support the successful implementation of inclusive education programs. Some of the studies above illustrate that there is a diversity between success and obstacles faced when running an inclusive school so that the role and relationship between parents and the school are very important in supporting the success of children.

Parent satisfaction is an important part of supporting children's education. The relationship test results stated that the mother's satisfaction was significantly positively related to father's satisfaction. Therefore, when the mother is satisfied with the educational services obtained, the father will feel the same way. Research from the Evidence, Data \& Knowledge Group Ministry of Education (2016) illustrates that seventy-one per cent (71.0\%) of parents and educators $(59.0 \%)$ are satisfied with the overall quality of service delivery and overall $(64.0 \%)$ of respondents are satisfied with children with needs. Specifically, feel satisfaction with the educational services received. This means that the mother's satisfaction with educational services will be related to the father's satisfaction. According to Evidence, Data \& Knowledge Group Ministry of Education (2016), this satisfaction can be described when parents provide positive comments about the educational services received and focus on staff professionalism, including competence, skills, experience, hard work, friendliness, and trying to build good relationships. Good with family, and parents feel supported and heard their feelings. These positive comments will relate to the progress of the child's development.

This study also shows that the results of father involvement also have a significant positive relationship with father satisfaction. This means that when the father is satisfied with 
the service from the school, it will optimize the father's involvement in supporting and participating in activities at school, creating a conducive and supportive environment for children learning at home, and having good relationships with parties at school. The level of satisfaction (direct reported satisfaction) is influenced by the father's assessment of the performance of basic education services (Rahma \& Hartoyo, 2010). Herien et al. (2009), in a study entitled a survey of parental satisfaction with basic education services provided by the school's decentralized system showed a link between satisfaction with services and parental involvement. This study shows that parental involvement is related to the school's efforts to establish communication with parents and provide information to parents regarding the education process of their children. In general, for all levels of education (elementary and junior high), parents rated their satisfaction with parental involvement in their child's education process as being moderate and close to satisfied. Doherty, Fitzgerald, and Matthews (2000) show that parental satisfaction with childcare services for children with special needs is associated with communication with professionals, individual programs that are regularly updated with the involvement of the parents concerned, and the addition of assistive services and special interventions. The involvement of parents in schools also requires the role of the school who also provides services so that parents can be involved (Afolabi, 2014).

Mother's involvement has a significant positive relationship with mother's education, which means that mothers who have higher education have sufficient knowledge, abilities, and skills to understand the needs of their children so that mothers will often be involved in children's activities both in parenting and education. Mothers who know inclusive education will participate in choosing schools, school activities, and actively support children's development at school or at home, so mother's education is very important in relation to mother's involvement in education. The results of research conducted by Zuna (2007) which states that the involvement of mothers with children with special needs in children's education usually focuses on child development rather than involvement in school and interactions at school, such as activities at school. Eagle (1989) states that parental involvement in children's education has a significant relationship with social background, including the level of parental education. Al-Matalka (2014) research also states that parents with higher education will be more involved in children's education. Mother's age has a significant positive relationship with mother's satisfaction. In addition, the results of the influence test also show that mother's age has a significant positive effect on mother's satisfaction. This shows that the more mature the mother, the more optimal the knowledge and skills so that she can assess and feel her satisfaction well. In Rahma and Hartoyo (2010) research, more mature respondents can increase satisfaction compared to younger ages. The more mature mother's age will have sufficient knowledge and views in assessing the inclusive education services received.

The results show a significant negative relationship between the mother's satisfaction with the father's education. When the father has a fairly high education, the father will have a different view in assessing the educational services received. This will make the mother feel less satisfied with the educational services received because fathers with higher education have various demands and views. Lundy's research (2011) states that parents who have a high education usually have high expectations of children's educational services, so parents tend to be difficult to be satisfied.

Father involvement is negative related significantly to the child's age and the length of time getting inclusive services. The involvement of fathers decreases as their children get older. This condition can occur if the father is so busy with his work that he cannot take the time to be involved in his child's education. Meanwhile, the age of the child who is getting older is considered by the father to be independent and make adjustments well. Fantuzzo, Tighe, and Childs (2006) compared parents who work part-time and work full time, in their research results that parents who work full time tend to be less involved in school. Another result also states that the longer they get inclusive services from schools, the less involved fathers are. This condition can occur if the school system does not provide information. Even though they have received services for a long time, the father feels less involved. Blok, Peetsma, and Roede (2007) the 
purpose of the education system to involve parents has not been achieved, so that parents feel that their suggestions or ideas are not being responded to well by the school, and other results state that the involvement of the active role of parents is not optimal related to parental satisfaction. The school service system is still lacking. Hornby and Lafaele (2011) state that parental involvement at home and school is necessary to implement individual education for parents with children with learning difficulties or disabilities. In this study, there are also several examples of partnerships or collaborations involving parents at home with the school, including preparing a parent's room, providing parental education and freeing class teachers to make home visits.

This study also explains that father involvement and mother satisfaction significantly affect father satisfaction with inclusive services. Father satisfaction also has a significant positive effect on mother's satisfaction with inclusive services. When fathers are often involved and communicate well with the school, it will optimize father's satisfaction with the inclusive education services received. This means that if the father is satisfied with the services obtained from the school, the father will participate in supporting and playing an active role in the child's learning process both at school and at home. Likewise, when fathers are satisfied with inclusive services at school, the mother's satisfaction will also be more optimal. According to Fantuzzo, McWayne, and Perry (2004), the dimensions of parental involvement are differently related to student learning and outcomes of classroom behaviour adjustment. This study also states that parental involvement will also be related to children's self-efficacy and school adjustment. Optimizing parental involvement at school with parental involvement at home can reduce the risk of children's behaviour problems and create a conducive and supportive environment for children to learn. Research by Salisbury and Evans (1988) shows that parents of children with special needs have more opportunities to be involved than parents in regular schools, satisfaction with educational services obtained will also be related to parental participation in assisting children in learning. Service satisfaction felt by parents is good, but caregivers of children with special needs want to see more parental involvement in caring for and participating in child care (Doherty, Fitzgerald, \& Matthews, 2000). Blok, Peetsma, and Roede (2007) explain that parental involvement in education plays a very important role in school decision-making. For example, choosing schools, assessing school services, and participating in school activities will affect parents' satisfaction with school services.

Another study from Griffith (1996), parent-school communication and school climate, showed the strongest direct effect on parental satisfaction, and the indirect effect of parental satisfaction was from school climate through informing parents. In addition, the relationship between parental involvement and satisfaction was moderated by how well parents were treated, informed, empowered and involved by the school and their perception of a positive school climate. The results of Habing's research (2004) describe that parent are satisfied if the school involves them in the meeting process. Schools and parents can work together and communicate well to make joint decisions according to children with special needs. Blok, Peetsma, and Roede (2007) explained that most of parents of children with special needs are satisfied with the educational services provided at the school. However, parents still feel that their advice is not well received by the school. This means that parental satisfaction between father and mother is interrelated in assessing the performance of school education services. Fantuzzo, Tighe, and Childs (2006), in their research comparing single parents and both parents, stated that single parents are less involved and associated with school so that their satisfaction with education is lower.

Meanwhile, children who have complete parents can share time at home and at school as well as responsibility for children's education so that satisfaction is better. This means that the role of both parents is very important in achieving satisfaction with children's education. However, this study has limitations, including the data collection technique used by selfadministered, so it cannot dig deeper into information. In addition, the purposive sampling 
method is still not representative of the overall model and type of inclusive school services to measure parental satisfaction with services in schools.

\section{Conclusion and Recommendation}

\section{Conclusion}

All children with special needs in this study have intellectual disabilities, which are categorized into three types of special needs, namely mental retardation (IQ <70), borderline (IQ 70-79), and slow learners (IQ 80-90). The results showed that the proportions of the three were not much different in this study; namely borderline as much as 37.0 per cent, mental retardation by 33.0 per cent, and slow learners by 30.0 per cent. The correlation test results showed that the higher the mother's satisfaction with the inclusive education of children with special needs, the higher the father's satisfaction. In addition, fathers with special needs who are increasingly involved in inclusive education are also closely related to the higher father satisfaction. Interestingly, the father's decreasing involvement was found in fathers with increasing age of special needs children, and the longer they received inclusive services.

Meanwhile, mothers who have high involvement are mothers with higher education. In addition, the results also found that mothers who were older and had a lower husband's education had higher satisfaction with the inclusive education of their children. Finally, the effect test found that the father's satisfaction was significantly affected by the father's involvement and mother's satisfaction. In contrast, mother's age and the father's satisfaction were significantly affected by mother's age.

\section{Recommendation}

Based on the study results, it is still necessary to optimize the involvement of parents with schools to support children's growth and development. Therefore, the involvement of parents at home, at school and their relationship with the school is very important to seek and support the optimal implementation of inclusive education for children. The results of this study also confirm that fathers' participation in supporting children's education plays a very significant role. Father's satisfaction in receiving inclusive education services is closely related to father's involvement at home, at school, or his relationship with parties at school. In addition, the relationship between parents and the school needs to be optimized by establishing informative communication. Schools provide opportunities for teachers to develop their skills according to the specificity of SNC. Therefore, apart from mothers who are traditionally more involved in the Indonesian family's role in parenting, fathers who are more involved will determine the success of the process of childcare and education.

\section{References}

Abdullah, A. (2020). Pengaruh sistem informasi manajemen pendidikan dan kompetensi sosial guru terhadap kepuasan orang tua siswa SD Islam Al Azhar 2 Pasar Minggu. (Tesis). Institut PTIQ Jakarta: Jakarta

Afolabi, O. E. (2014). Parents involvement in inclusive education: an empirical test for the psycho-educational development of learners with special educational needs 
(SENs). International Journal of Educational Administration and Policy Studies, 6(10), 196-208. Doi:10.20489/intjecse.30749

Agustin, I. (2016). Manajemen pendidikan inklusi di Sekolah Dasar Sumbersari 1 Kota Malang. Education and Human Development Journal, 1(1). 27-34. Doi: https://doi.org/10.33086/ehdj.v1i1.290

Al-Matalka, F. I. M. (2014). The influence of parental socioeconomic status on their involvement at home. International Journal of Humanities and Social Science, 4(5), 146-154.

Alotaibi, B. M. (2017). Rural, urban, and small town/suburban parents' satisfaction toward special education services for young children with disabilities in Northwest Ohio. (Disertasi). University of Toledo

Blok, H., Peetsma, T. T. D., \& Roede, E. (2007). Increasing the involvement of parents in the education of special-needs children. The British Journal of Development Disabilities, 53(104), 3-16.

Boscardin, M. L., \& Jacobson, S. (1997). The inclusive school: Integrating diversity and solidarity through community-based management. Journal of Educational Administration, 35(5), 466-476. Doi: https://doi.org/10.1108/09578239710184600

Brydges, C., \& Mkandawire, P. (2018). Perceptions and experiences of inclusive education among parents of children with disabilities in Lagos, Nigeria. International Journal of Inclusive Education, 24(6), 645-659. Doi: https://doi.org/10.1080/13603116.2018.1480669

Doherty, K., Fitzgerald, M., \& Matthews, P. (2000). Services for autism in Ireland. The Irish Journal of Psychology, 21(1-2), 50-69. Doi: https://doi.org/10.1080/03033910.2000.10558239

Eagle, E. (1989). Socioeconomic Status, Family Structure, and Parental Involvement: The Correlates of Achievement

Evans, J., \& Lunt, I. (2002). Inclusive education: are there limits?. European Journal of Special Needs Education, 17(1), 1-14. Doi: https://doi.org/10.1080/08856250110098980

Evidance, Data, and Knowledge Group. (2016). Special Education Services 2015 Client Satisfaction Survey. Ministry of Education in New Zealand

Fantuzzo, J., McWayne, C., Perry, M. A., \& Childs, S. (2004). Multiple dimensions of family involvement and their relations to behavioral and learning competencies for urban, low-income children. School Psychology Review, 33(4), 467-480. Doi: https://doi.org/10.1080/02796015.2004.12086262

Fantuzzo, J., Tighe, E., Childs, S. (2006). Parent satisfaction with educational experiences scale: a multivariate examination of parent satisfaction with early childhood education programs. Early Childhood Research Quarterly. 21(2),142152. Doi: 10.1016/j.ecresq.2006.04.002

Griffith, J. (1996). Test of a model of the organizational antecedents of parent involvement and satisfaction with public education. Human Relations, 49(12), 1549-1571. Doi: https://doi.org/10.1177\%2F001872679604901204

Hehir, T., Grindal, T., Freeman, B., Lamoreau, R., Borquaye, Y., \& Burke, S. (2016). A Summary of the Evidence on Inclusive Education. Abt Associates.

Heiserman, R. J. (1994). Parent involvement and parent satisfaction with public schools. (Disertasi). Northern Arizona University 
Herien, P., Sarma, M., Hartoyo, H., Latifah, M., Herawati, T. (2009). Laporan akhir penelitian survei kepuasan terhadap pelayanan pendidikan dasar yang disediakan oleh sistem desentralisasi sekolah. LPPM-IPB

Hidalgo, N. J., Mcintyre, L. L., \& Mcwhirter, E. H. (2015). Sociodemographic differences in parental satisfaction with an autism spectrum disorder diagnosis. Journal of Intellectual and Developmental Disability, 40(2), 147-155. Doi: 10.3109/13668250.2014.994171

Hornby, G., \& Lafaele, R. (2011). Barriers to parental involvement in education: An explanatory model. Educational Review, 63(1), 37-52. Doi: https://doi.org/10.1080/00131911.2010.488049

Indrawati, A. (2011). Pengaruh kualitas layanan lembaga pendidikan terhadap kepuasan konsumen. Jurnal Ekonomi Bisnis, 16(1), 25-35.

Kemendikbud. (2016). Gambaran Sekolah Inklusif Di Indonesia: Tinjauan Sekolah Menengah Pertama. Bidang Pendayagunaan dan Pelayanan Data. - Jakarta: Pusat Data dan Statistik Pendidikan dan Kebudayaan

Kementerian Pendidikan dan Kebudayaan. (2011). Pedoman Umum Penyelenggaraan Pendidikan Inklusif (Sesuai Permendiknas No 70 Tahun 2009). Jakarta: Kementerian Pendidikan dan Kebudayaan.

Lundy, H. F. (2011). Parental stress, socioeconomic status, satisfaction with services, and family quality of life among parents of children receiving special education services. (Dissertation). United States: Georgia State University.

Habing, M. (2004). The individualized education plan: Parental satisfaction and involvement. (Thesis). Eastern Illinois University

Musyafira, I. D., \& Hendriani, W. (2021). Sikap guru dalam mendukung keberhasilan pendidikan inklusi. Jurnal Kependidikan: Jurnal Hasil Penelitian dan Kajian Kepustakaan di Bidang Pendidikan, Pengajaran dan Pembelajaran, 7(1), 75-85. Doi: 10.33394/jk.v7i1.3105

Ningsih, D. A., Imron, A., \& Triwiyanto, T. (2018). Hubungan persepsi tentang kualitas dan pelayanan pendidikan dengan kepuasan orang tua siswa sekolah menengah kejuruan negeri. JAMP: Jurnal Administrasi dan Manajemen Pendidikan, 1(2), 245-254. Doi: http://dx.doi.org/10.17977/um027v1i22018p245

Pratiwi, J. C. (2016). Sekolah inklusi untuk anak berkebutuhan khusus: tanggapan terhadap tantangan kedepannya. Prosiding Ilmu Pendidikan 1, no. 2

Rahma, A., \& Hartoyo, H. (2010). Pengaruh karakteristik orangtua dan sekolah terhadap tingkat kepuasan pelayanan pendidikan dasar. Jurnal Ilmu Keluarga \& Konsumen, 3(2), 164-172. Doi: https://doi.org/10.24156/jikk.2010.3.2.164

Robiyansah, I. E. (2020). The development of inclusive education management model: practical guidelines for learning in inclusive school. Journal of Education and $\begin{array}{llll}\text { Learning } \quad \text { (EduLearn), } & \text { 80-86. }\end{array}$ http://dx.doi.org/10.11591/edulearn.v14i1.13505

Salisbury, C., \& Evans, I. M. (1988). Comparison of parental involvement in regular and special education. Journal of the Association for Persons with Severe Handicaps, 13(4), 268-272. Doi: https://doi.org/10.1177\%2F154079698801300405

Sari, T. N., \& Prasetya, M. N. (2020). Dapatkah kepemimpinan kepala sekolah, motivasi guru dan kualitas pelayanan pendidikan mempengharuhi kepuasan orang tua siswa. EduTech: Jurnal Ilmu Pendidikan dan Ilmu Sosial, 6(1), 87-97. Doi: http://dx.doi.org/10.30596\%2Fedutech.v6i1.4399 
Setiawati, D. N. A. E. (2019). Teknik penguatan positif untuk anak dengan keterbatasan intelektual. Procedia: Studi Kasus Dan Intervensi Psikologi, 7(1), 1-12. Doi: https://doi.org/10.22219/procedia.v7i1.12976

Subbey, M. (2017). Facilities available for teachers to support the learning needs of children with disabilities in the inclusive school setting. American Scientific Research Journal for Engineering, Technology, and Sciences (ASRJETS), 32(1), 18-32.

Sujarwanto, M., Riyanto, Y., \& Ashar, M. (2018). The management of students with special needs in inclusive school. Atlantis Press: Advances in Social Science, Education and Humanities Research. 1st International Conference on Education Innovation (ICEI 2017). 173: 312-315

Sularyo, T. S., \& Kadim, M. (2000). Retardasi mental. Sari Pediatri, 2(3), 170-177. Doi: https://dx.doi.org/10.14238/sp2.3.2000.170-7

Sutisna, D., Indraswati, D., Nursaptini, N., Novitasari, S., \& Sobri, M. (2020). Penerapan program pendidikan inklusi Di SDN 1 Sangkawana Lombok Tengah. Progres Pendidikan, 1(2), 115-127.

Tarnoto, N. (2016). Permasalahan-permasalahan yang dihadapi sekolah penyelenggara pendidikan inklusi pada tingkat SD. Humanitas: Jurnal Psikologi Indonesia, 13(1), 50-61.

Utami, M. N., \& Putra, W. B. (2020). Fasilitas ruang khusus pada sekolah inklusi Binar Indonesia (Bindo) di Bandung. Jurnal Arsitektur TERRACOTTA, 2(1), 34-43. Doi: https://doi.org/10.26760/terracotta.v2i1.4289

Wehrmann, L. A. (2015). Stress levels of parents of homeschooled versus publicschooled special needs children. (Disertasi). Walden University.

Zuna, N. I. (2007). Examination of family-professional partnerships, parent-teacher communication, and parent involvement in families of kindergarten children with and without disabilities. Retrieved from ProQuest Dissertations \& Theses Global. (3266511). 